\title{
Sala de recursos multifuncional em escolas do campo: direito assegurado?
}

\author{
Multifunctional resources classroom in country schools: \\ assured right?
}

\author{
Debora Teresa Palma ${ }^{1}$ \\ Relma Urel Carbone Carneiro ${ }^{2}$
}

\section{Resumo}

O Atendimento Educacional Especializado é a base para o desenvolvimento de uma escola inclusiva, no tocante às pessoas com algum tipo de deficiência. O presente artigo tem como objetivo descrever e analisar a organização de três Salas de Recursos Multifuncional em Escolas do Campo de um municipio do interior paulista. Para tanto, seguiu-se uma abordagem quanti-qualitativa de pesquisa que teve como procedimento metodológico o Estudo de Caso. Para coleta dos dados foram utilizados questionários, observações, registro fotográfico e análise de documentos escolares. Será apresentado um recorte das observações, fotos e do questionário respondido por 31 professores. Os resultados apontam que as três unidades escolares não apresentam espaço próprio para funcionamento da Sala de Recursos Multifuncional, inclusive esta situação continua a mesma dois anos após a realização da pesquisa. Assim sendo, cabe a reflexão se os direitos assegurados nas politicas públicas sobre Educação Especial na perspectiva Inclusiva são validados nas escolas do campo.

Palavras chaves: Educação do Campo. Educação Especial. Atendimento Educacional Especializado. Sala de Recursos Multifuncional.

\footnotetext{
${ }^{1}$ Mestre em Educação Escolar pelo Programa de Pós-Graduação da Faculdade de Ciências e Letras da UNESP, Campus de Araraquara/SP. E-mail: debora-palma@hotmail.com.

2 Docente do Departamento de Psicologia da Educação e do Programa de Pós-Graduação em Educação Escolar da Faculdade de Ciências e Letras da UNESP, Campus de Araraquara/SP. E-mail: relmaurel@fclar.unesp.br.
} 


\section{Abstract}

The Specialized Educational service is the base for the development of an inclusive school, concerning people with some kind of deficiency. The aim of this article is to describe and analyze the organization of three Multifunctional Resources Classrooms in country schools of a São Paulo State interior county. Therefore, a quantitative and qualitative approach of research was followed and it had as a methodological procedure the Case Study. For data collection, questionnaires, observations, photographic register, and analysis of school documents were used. A clipping of the observations, photos, and the questionnaire answered by 31 teachers will be presented. The results show that the three school units analyzed do not have a proper place for operating the Multifunctional Resources Classroom, and this situation is the same two years after the research. Thus, a reflection is necessary about if the assured rights in the public policies about Special Education in the Inclusive perspective are valid in country schools.

Key words: Country Education, Special Education, "AEE", Multifunctional Resources Classroom.

\section{Introdução}

O propósito da escola inclusiva é que ela tenha competência para desenvolver processos e estratégias de ensino e aprendizagem capazes de oferecer a todos os alunos, inclusive aos alunos com deficiência, condições de desenvolvimento acadêmico dentro de suas possibilidades, que os coloque de forma equânime em condições de acessarem oportunidades no mercado de trabalho e na vida. Considerando os alunos com deficiência, foco dessa pesquisa, para alcançar tal propósito, o sistema educacional precisa promover mudanças em termos de acesso ao currículo, de estratégias de ensino elaboradas em conjunto com professores especialistas em Educação Especial e de adequações físicas e organizacionais de acordo com a necessidade do aluno com deficiência. Enfim, a escola precisa conceber a inclusão no seu Projeto Político Pedagógico e colocar em funcionamento as medidas necessárias para promover a igualdade de condições e não apenas garantir a matrícula, pois este ato não é suficiente para termos uma Educação Inclusiva. 
$\mathrm{O}$ ato da matrícula não garante que o aluno com deficiência tenha oportunidade e acesso ao conhecimento como qualquer outro aluno sem deficiência. A inserção dele no ambiente escolar não constitui, automaticamente, sua aprendizagem. Para que isso aconteça é necessário conceber o conceito de inclusão, o qual significa mudança, transformação, alteração, trocar uma coisa por outra ou ainda tornar-se diferente do que era.

Dada essa nova concepção, o principal quesito não é a matrícula de alunos com ou sem deficiência, mas sim, a abertura da escola para oferecer educação a todos os alunos. E como esta escola ainda é idealizada, tendo em vista que historicamente não atendia a todos, a inclusão ainda não acontece de fato, pois como concepção, sugere mudança de valores e atitudes.

$\mathrm{Na}$ perspectiva da Educação Inclusiva, a Educação Especial se modificou, deixando de atuar isoladamente em classes especiais para funcionar como serviço de Atendimento Educacional Especializado (AEE), o qual consta na Política Nacional de Educação Especial na Perspectiva da Educação Inclusiva (BRASIL, 2008a), que, além deste tópico, apresenta outros aspectos para garantir o acesso, a participação e a aprendizagem dos alunos com deficiência. Este documento apresenta a definição do AEE:

O atendimento educacional especializado tem como função identificar, elaborar e organizar recursos pedagógicos e de acessibilidade que eliminem as barreiras para a plena participação dos alunos, considerando suas necessidades específicas. As atividades desenvolvidas no atendimento educacional especializado diferenciam-se daquelas realizadas na sala de aula comum, não sendo substitutivas à escolarização. Esse atendimento complementa e/ou suplementa a formação dos alunos com vistas à autonomia e independência na escola e fora dela. (BRASIL, 2008a, p.10)

Para complementar e esclarecer mais sobre esse serviço, o Decreto 7.611 de 17 de novembro de 2011 descreve os objetivos do AEE:

Art. $3^{\circ}$ São objetivos do atendimento educacional especializado:

I - prover condições de acesso, participação e aprendizagem no ensino regular e garantir serviços de apoio especializados de acordo com as necessidades individuais dos estudantes;

II - garantir a transversalidade da educação especial no ensino regular; 
III - fomentar o desenvolvimento dos recursos didáticos e pedagógicos que eliminem as barreiras no processo de ensino e aprendizagem; e

IV - assegurar as condições para a continuidade de estudos nos demais niveis, etapas e modalidades de ensino. (BRASIL, 2011, p.01)

Observa-se que esse serviço não substitui o currículo da escola regular, ele oferece uma assistência para que o aluno tenha acesso e condições de participar com autonomia da escola, desde a aprendizagem das diversas áreas do conhecimento até o campo do convivio social. Além disso, promove orientação do professor da sala comum para que consiga atuar com as diferenças no processo educativo, compartilhando um trabalho interdisciplinar e colaborativo.

Com o paradigma da escola inclusiva que pressupõe a educação de todos os alunos independentemente de quaisquer características nos ambientes comuns de ensino, a Educação Especial que, historicamente ocupou um espaço de substituição escolar para os alunos com deficiência, passou a exercer uma função complementar na escolarização de tais alunos. Essa complementaridade se dá na forma de oferecimento de AEE para os alunos com deficiência, transtornos globais de desenvolvimento e altas habilidades/superdotação, alunos público alvo da Educação Especial, matriculados em classes comuns de ensino, porém que necessitem de complementação ou suplementação do ensino oferecido.

Assim sendo, o AEE é um serviço que constantemente evidencia a necessidade de mudança no sistema educacional para criar as condições de participação de todos os alunos, isso porque ele integra a proposta pedagógica da escola regular e faz com que os professores repensem suas práticas de ensino, de forma a contemplar o aluno com deficiência que está na sua sala e tem o acompanhamento do professor especialista do AEE. Essa articulação, quando bem realizada, garante não somente a presença física do aluno com deficiência na sala regular, mas também, o acesso dele ao conhecimento dentro das suas possibilidades.

Cabe ressaltar que o AEE perpassa todos os niveis e modalidades de ensino e tem como objetivo fornecer recursos e orientação para o ensino 
adequado de acordo com o tipo de deficiência, mas para que isso se efetive é necessária uma mudança de valores e atitudes dos professores e da equipe pedagógica do sistema educacional. Primordialmente, é preciso romper com o paradigma da homogeneidade e do aluno ideal. Mesmo entre os alunos sem deficiência, há diferenças na aprendizagem, na maneira de receber e interagir com o conhecimento, nas preferências e habilidades específicas para uma determinada área. Também existem as diferenças determinadas pela condição social e emocional em que o aluno está inserido. Contudo, a escola precisa se tornar inclusiva porque necessita reconhecer que somos todos iguais na condição humana e em direitos, com pequenas variações denominadas diferenças. Torna-se necessário aceitar a diversidade existente na sociedade a qual se reflete na escola e olhar cada individuo como único, sem depositar expectativas daquele aluno idealizado, que se resume num aluno sem problemas de comportamento, com ótima estrutura familiar, que se sobressai em todas as disciplinas escolares com notas acima da média, que não apresenta dificuldade na aprendizagem e que tem perspectivas de futuro para o ingresso em universidades. Todo professor de sala regular espera esse aluno, porém a realidade é outra e fica mais acentuada quando estão diante de um aluno com deficiência, o qual exigirá ainda mais que se afaste do seu paradigma de aluno ideal.

O trabalho desenvolvido no AEE pelo professor especialista é a base fundamental para desenvolver o conceito de diversidade nas escolas. Para tanto, ele precisa se organizar num espaço adequado, a sala de recursos multifuncional (SRM), a qual precisa ter equipamentos, recursos de acessibilidade e materiais pedagógicos necessários à remoção de barreiras para promoção da escolarização do público alvo da educação especial.

No entanto, a Sala de Recursos Multifuncional é um espaço deixado em segundo plano, sem se efetivar o direito proposto pela legislação. Durante essa pesquisa realizada em nível de mestrado, concluída em 2016, em três escolas do campo de um municipio do interior paulista constatou-se a falta de estrutura para o desenvolvimento do AEE. Apresentaremos os resultados, 
elucidando também a situação atual em que se encontram essas escolas, dois anos após a pesquisa.

Como estamos apontando especificamente questões da interface entre Educação Especial e Educação do Campo, apresentaremos sobre a temática na seção que segue sobre o referencial teórico.

\section{Referencial teórico}

A Educação do Campo possui a mesma vertente da escola inclusiva, que considera o acesso ao conhecimento para todos independentemente da origem, condição social, deficiência, gênero, raça e da localização espacial em que o indivíduo resida. O espaço do campo possui muitas especificidades que a escola deve levar em consideração para que a educação de fato aconteça, proporcionando aos indivíduos campesinos o exercício prático do saber e consequente transformação da realidade.

A educação não acontece apenas de uma forma, a diversidade exige que tenhamos modelos educacionais diferenciados, como é o caso da realidade campesina que possui característica própria de estrutura sociocultural e econômica diferenciada.

A educação do campo envolve, de acordo com a Resolução 2/2008, as seguintes populações:

Art. $1^{\circ}$ A Educação do Campo compreende a Educação Básica em suas etapas de Educação Infantil, Ensino Fundamental, Ensino Médio e Educação Profissional Técnica de nivel médio integrada com o Ensino Médio e destina-se ao atendimento às populações rurais em suas mais variadas formas de produção da vida - agricultores familiares, extrativistas, pescadores artesanais, ribeirinhos, assentados e acampados da Reforma Agrária, quilombolas, caiçaras, indigenas e outros. (BRASIL, 2008c, p.01)

A garantia dos direitos desses grupos foi possível por meio de uma longa e tensa caminhada dos movimentos sociais para colocar a Educação do Campo na agenda de políticas públicas. É preciso garantir o acesso universal à educação. Como coloca Caldart (2004):

Somos herdeiros e continuadores da luta histórica pela constituição da educação como direito universal: um direito humano, de cada pessoa em vista de seu desenvolvimento mais pleno, e um direito 
social, de cidadania ou de participação mais crítica e ativa de todos na dinâmica da sociedade. Como direito não pode ser tratado como serviço e nem como política compensatória; muito menos como mercadoria. (CALDART, 2004, p.26)

Esse direito universal não é somente a presença de todos na escola como se ela fosse um serviço para produzir indicadores estatísticos de matrículas. É preciso ter qualidade para formar pessoas capacitadas com consciência crítica para continuar lutando pelos seus direitos.

A Educação do Campo não pode estar atrelada às necessidades e demandas do mercado. As políticas públicas priorizam a escolarização que demanda mais qualificação. Com a expansão do agronegócio e a modernização do campo, está sendo necessária mais qualificação. Isto não justifica a Política porque esse sistema acaba expulsando os trabalhadores do campo e a luta é sempre pela permanência na terra.

$\mathrm{O}$ avanço do capitalismo que prioriza a monocultura exportadora no campo é um processo excludente, no qual muitos camponeses vão para as cidades. As lutas sociais possuem um papel importante de transformar latifúndios em assentamentos, trabalhando com a agricultura familiar que também pode gerar renda e ser sustentável, estando em harmonia com o meio ambiente.

A Educação do Campo é fruto da luta dos movimentos sociais, por isso, ela deve levar em conta os interesses e o desenvolvimento sociocultural e econômico destas populações que residem no campo. A escola precisa estar vinculada às causas, aos desafios, aos sonhos, à história e à cultura do trabalhador do campo, ela não pode ser tratada como um resíduo do sistema educacional brasileiro.

É preciso superar a dicotomia da cidade versus campo, nenhum lugar é melhor do que outro, na verdade o campo complementa o urbano e viceversa. Devemos superar a visão de que o moderno e mais avançado é sempre o urbano. O progresso não pode ser medido pela diminuição da população rural.

Caldart (2008) coloca que a educação do campo deve ser pensada sempre na tríade Campo, Política Pública e Educação: 
É importante ter presente que está em questão na Educação do Campo, pensada na triade Campo - Política Pública - Educação e desde os seus vínculos sociais de origem, uma política de educação da classe trabalhadora do campo, para a construção de um outro projeto de campo, de país, e que pelas circunstâncias sociais objetivas de hoje, implica na formação dos trabalhadores para lutas anti-capitalistas, necessárias a sua própria sobrevivência: como classe, mas também como humanidade. Formação que inclui a afirmação de novos protagonistas para pensar/construir esta politica: os próprios trabalhadores do campo como sujeitos construtores de seu projeto de formação. (CALDART, 2008, p. 72)

Na verdade, está embutida no projeto de Educação do Campo, a luta social pela Reforma Agrária e a agricultura familiar, com vistas a combater o latifúndio e o agronegócio do sistema capitalista. E também, a luta pelo direito ao saber, ao conhecimento e à cultura produzida socialmente. Os sujeitos do campo não são inferiores, lutam por uma nova concepção de campo, na qual haja transformação social, respeito pela diversidade e garantia de direitos.

A mudança na Política aconteceu quando a educação foi colocada no âmbito do direito e dever do Estado. Como coloca Arroyo (2004):

A lição a aprender é que somente a colocação da educação dos povos do campo no terreno dos direitos poderá significar uma garantia de um trato público. Poderá afirmar a autonomia da educação em relação a qualquer troca política e a lógica da mercadoria. Afirmar a igualdade dos direitos humanos independente de toda diversidade inclusive territorial. O lugar onde se vive não pode condicionar os direitos. (ARROYO, 2004, p. 101-102).

O direito é universal, independente da condição social. O Estado precisa universalizar os direitos que vão se materializar por meio das políticas públicas. Diante disso, devemos também pensar que nesse segmento territorial existem pessoas com deficiência que também precisam ter os seus direitos garantidos, levando em consideração as particularidades e dificuldades que a condição territorial impõe ao seu desenvolvimento. Assim sendo, não podemos ter políticas generalistas. Posteriormente, discutiremos como a Educação Especial se relaciona com a Educação do Campo, analisando a legislação, a produção científica e as consonâncias e dissonâncias entre essas duas áreas. 
Como uma política federal para todo o sistema de ensino, o AEE abrange a educação do campo que, segundo a Resolução 2/2008 (BRASIL, 2008c) destina-se ao atendimento das populações rurais em suas mais variadas formas de produção de vida - agricultores familiares, extrativistas, pescadores artesanais, ribeirinhos, assentados e acampados da Reforma Agrária, quilombolas, caiçaras, indigenas e outros.

O documento da Política Nacional de Educação Especial na Perspectiva da Educação Inclusiva (BRASIL, 2008a) traz a questão de olhar de modo particular para as pessoas com deficiência inseridas nas diversas comunidades ou grupos sociais:

A interface da educação especial na educação indígena, do campo e quilombola deve assegurar que os recursos, serviços e atendimento educacional especializado estejam presentes nos projetos pedagógicos construídos com base nas diferenças socioculturais desses grupos (BRASIL, 2008a, p.17)

A Resolução 2/2008 referente a políticas públicas de atendimento da Educação Básica do Campo, afirma:

$\S 5^{\circ}$ Os sistemas de ensino adotarão providências para que as crianças e os jovens portadores de necessidades especiais (sic), objeto da modalidade de Educação Especial, residentes no campo, também tenham acesso à Educação Básica, preferentemente em escolas comuns da rede de ensino regular (BRASIL, 2008 c, p.1).

Como podemos observar, a legislação garante que as pessoas com deficiências residentes em área rural tenham acesso à escola e aos serviços de apoio à inclusão escolar, respeitando suas diferenças socioculturais.

Vale lembrar que essas duas áreas da educação tiveram um histórico de desatenção e exclusão, mesmo sendo considerado um direito social ele foi negado por muitas gerações. No caso das pessoas com deficiência, a segregação ocorreu devido a um olhar de incapacidade destes sujeitos e, no caso da população do campo, o desinteresse foi causado pela visão do campo como um lugar arcaico, de atraso, onde não aconteceria o desenvolvimento.

Outra particularidade que envolve Educação Especial e Educação do Campo é a ausência de produção de conhecimento na área. Como comentado por Caiado Meletti (2011a): 
Assim, o silêncio da produção científica sobre a interface da Educação Especial na educação do campo nos coloca mais um grande desafio. Cabe à universidade cumprir seu papel na produção de conhecimento que responda ao direito à educação escolar de todos os alunos com deficiência, inclusive dos que vivem no campo. Direito à escola que compreende matrícula, permanência, apropriação do conhecimento para participação social e ao respeito às especificidades do sujeito desencadeadas não só pela condição de deficiência, mas também pelas peculiaridades culturais e sociais da vida no campo. (CAIADO, MELETTI, 2011a, p.103)

\section{Consonâncias e dissonâncias entre Educação Especial e Educação do Campo}

A proposta, neste momento, é de reflexão sobre como essas duas modalidades de educação, a especial e a do campo, compartilham aspectos muito próximos em relação à sua história e constituição. Por outro lado, será mostrada a distância que separa uma da outra. A Educação Especial tem avançado em termos de políticas públicas, mas esse avanço parece não atingir a Educação do Campo. É como se não existissem pessoas com deficiência nas comunidades quilombolas, caiçaras, indigenas, ribeirinhos, agricultores familiares, acampamentos e assentamentos da Reforma Agrária, entre outros.

Iniciemos com os aspectos consonantes. Em primeiro lugar essas duas áreas tiveram seus direitos negligenciados historicamente, que começaram a se modificar a partir da universalização dos direitos com a Constituição de 1988 (BRASIL, 1988). Em segundo lugar apesar das lutas e a garantia de direitos na legislação, ainda existem muitos problemas de implantação e cumprimento das leis, os quais precisam ser sanados. Em terceiro lugar, os sujeitos dessas duas áreas possuem especificidades que precisam ser levadas em consideração dentro do processo educativo. Como coloca Piovesan (2006):

A efetiva proteção dos direitos humanos demanda não apenas politicas universalistas, mas específicas, endereçadas a grupos socialmente vulneráveis, como vitimas preferenciais da exclusão. Isto é, a implementação dos direitos humanos requer a universalidade e a indivisibilidade desses direitos, acrescidas do valor da diversidade. Ao processo de expansão dos direitos humanos, soma-se o processo de especificação de sujeitos de direitos. (PIOSEVAN, 2006, p. 26) 
Os indivíduos com deficiência que residem em regiões rurais são duplamente vulneráveis, pelo lugar onde vivem e pela condição imposta por sua deficiência. Desta forma, as políticas não podem ser apenas universalistas, elas precisam garantir o atendimento às especificidades, considerando as diferenças. Neste sentido, ainda precisamos fazer aparecer nos documentos oficiais da Educação do Campo a existência dos indivíduos com deficiência, para garantir seus direitos peculiares.

O último documento referente às políticas de Educação do Campo é o Decreto n. 7.352/2010 (BRASIL, 2010) que dispõe sobre a Política de Educação do Campo e o Programa Nacional de Educação na Reforma Agrária. Analisando esse documento, é possivel perceber a ampliação dos direitos que começou restringindo-se somente à Educação Básica. Em seu Artigo $4^{\circ}$ inclui a oferta de Educação Infantil, a Educação de Jovens e Adultos com qualificação voltada ao desenvolvimento sustentável do campo e o acesso ao ensino superior.

Outro aspecto positivo é que ele trata da garantia de infraestrutura para as escolas e também de transporte que respeite as peculiaridades regionais. Juntamente, prescreve sobre a Formação de Professores para atuar com as especificidades das populações do campo.

Como negativo, podemos citar a ausência da modalidade de Educação Especial. A impressão que temos é que, nestas regiões, não há pessoas com deficiência que necessitem de escola e de atendimento especializado. As escolas do campo precisam estar preparadas para atender o público alvo da Educação Especial, conforme definido na Política Nacional de Educação Especial na Perspectiva da Educação Inclusiva (BRASIL, 2008a).

O Plano Nacional de Educação (PNE) de 2014, Lei N.13.005/14 (BRASIL, 2014), nos seus itens referentes à Educação do Campo, coloca a importância de considerar as necessidades específicas das populações do campo assegurando equidade educacional.

Art. 8o Os Estados, o Distrito Federal e os Municípios deverão elaborar seus correspondentes planos de educação, ou adequar os 
planos já aprovados em lei, em consonância com as diretrizes, metas e estratégias previstas neste PNE, no prazo de 1 (um) ano contado da publicação desta Lei.

$\S 1$ o Os entes federados estabelecerão nos respectivos planos de educação estratégias que:

I - assegurem a articulação das politicas educacionais com as demais politicas sociais, particularmente as culturais;

II - considerem as necessidades específicas das populações do campo e das comunidades indígenas e quilombolas, asseguradas a equidade educacional e a diversidade cultural;

III - garantam o atendimento das necessidades específicas na educação especial, assegurado o sistema educacional inclusivo em todos os niveis, etapas e modalidades; (BRASIL, 2014, p. 03)

A equidade contempla o conceito de que pessoas diferentes têm necessidades diferentes, por isso as diferenças precisam ser respeitadas para garantir o direito. E este conceito se aplica tanto às populações do campo quanto às pessoas com deficiência.

A meta quatro do PNE, é referente à Educação Especial:

Meta 4: universalizar, para a população de 4 (quatro) a 17 (dezessete) anos com deficiência, transtornos globais do desenvolvimento e altas habilidades ou superdotação, o acesso à educação básica e ao atendimento educacional especializado, preferencialmente na rede regular de ensino, com a garantia de sistema educacional inclusivo, de salas de recursos multifuncionais, classes, escolas ou serviços especializados, públicos ou conveniados. (BRASIL, 2014, p. 06)

E como uma das estratégias, temos a necessidade de implantar Salas de Recursos Multifuncionais e realizar a formação de professores para o atendimento educacional especializado nas escolas urbanas, do campo, indigenas e de comunidades quilombolas:

4.3) implantar, ao longo deste PNE, salas de recursos multifuncionais e fomentar a formação continuada de professores e professoras para o atendimento educacional especializado nas escolas urbanas, do campo, indigenas e de comunidades quilombolas; (BRASIL, 2014, p. 06)

De fato, isso precisa acontecer para garantir que as pessoas com deficiência que vivem em outras regiões com particularidades tenham acesso à educação e aos atendimentos especializados de saúde. Esses sujeitos não podem mais viver isolados da sociedade e invisiveis para as politicas públicas. 
Em relação aos aspectos dissonantes entre uma modalidade e outra, percebemos que as legislações pouco citam a necessidade de interface entre ambas. Também como colocam Caiado e Meletti (2011a) o silêncio sobre como vivem as pessoas com deficiência no campo é revelado pela ausência e produção científica na área.

Alguns indicadores educacionais da educação especial no campo também mostram a dimensão desse distanciamento entre as áreas. Caiado e Meletti (2011b) analisaram por meio dos microdados do Censo da Educação Básica, disponibilizados pelo INEP, as matrículas dos alunos que vivem no campo no Estado de São Paulo no período de 2007 a 2010. Deste estudo, queremos destacar as duas tabelas a seguir:

Tabela 1 - Matrículas de alunos que vivem no campo por tipo de deficiência no estado de São Paulo $(2007 / 2010)$

\begin{tabular}{ccccccccccc}
\hline Ano & Cegueira & $\%$ & Surdez & $\%$ & DF & $\%$ & DI & $\%$ & Total & $\%$ \\
\hline 2007 & 35 & 1,04 & 209 & 6,22 & 316 & 9,41 & 2795 & 83,30 & 3355 & 100 \\
2008 & 40 & 0,81 & 245 & 4,98 & 443 & 9,01 & 4185 & 85,18 & 4913 & 100 \\
2009 & 58 & 0,74 & 332 & 4,24 & 690 & 8,83 & 6732 & 86,17 & 7812 & 100 \\
2010 & 68 & 0,70 & 366 & 3,78 & 1167 & 12,05 & 8081 & 83,46 & 9682 & 100 \\
\hline
\end{tabular}

Fonte: CAIADO; MELETTI, $2011 \mathrm{~b}, \mathrm{p} .180$.

Tabela 2 - Matrículas de alunos que vivem e estudam no campo por tipo de deficiência no estado de São Paulo (2007/2010)

\begin{tabular}{ccccccccccc}
\hline Ano & Cegueira & \% & Surdez & $\%$ & DF & \% & DI & \% & Total & $\%$ \\
\hline 2007 & 11 & 2,47 & 48 & 10,81 & 77 & 17,34 & 308 & 69,36 & 444 & 100 \\
2008 & 10 & 1,47 & 48 & 7,09 & 102 & 15,06 & 517 & 76,36 & 677 & 100 \\
2009 & 10 & 0,93 & 52 & 4,87 & 178 & 16,68 & 827 & 77,50 & 1067 & 100 \\
2010 & 8 & 0,60 & 61 & 4,57 & 222 & 16,65 & 1042 & 78,16 & 1333 & 100 \\
\hline
\end{tabular}

Fonte: CAIADO; MELETTI, $2011 \mathrm{~b}, \mathrm{p} .181$.

Ao compararmos as duas tabelas, podemos observar que do total de alunos que vivem no campo, temos um número reduzido daqueles que estudam no campo. Por exemplo, no ano de 2010, na Tabela 1, temos um total de 9682 matrículas de alunos com deficiência que vivem no campo, desse número apenas 1333 frequentam a escola no campo como vemos na Tabela 2. E se olharmos os dados dos anos anteriores, o mesmo ocorre. Se esses alunos estão tendo que procurar escolas fora do campo é porque as escolas do campo não possuem estrutura para atendê-los. Percebemos, 
então, a distância que existe entre Educação do Campo e Educação Especial e, quando esses alunos com deficiência são recebidos em escolas urbanas, existe duplamente o conflito de identidade ocasionado pela diferença da deficiência e do contexto social e territorial.

\section{Metodologia}

A pesquisa desenvolvida em nível de mestrado no Programa de PósGraduação em Educação Escolar da FCL/CAr da Unesp, teve como objetivos analisar, nas escolas do campo de um município no interior do Estado de São Paulo, o Atendimento Educacional Especializado em Salas de Recursos Multifuncional e, descrever o AEE no âmbito escolar além de identificar a percepção, acerca da deficiência, dos pais e professores que convivem com os alunos que frequentam a SRM nestas escolas do campo. A pesquisa seguiu uma abordagem quanti-qualitativa, teve como procedimento metodológico o Estudo de Caso e como instrumentos de coleta de dados fez uso de questionários, observações, registro fotográfico e análise de documentos escolares. A pesquisa analisou o AEE de 3 escolas do campo pertencentes a um mesmo município. Assumimos esta realidade porque nas unidades selecionadas o sistema da Educação Especial segue o mesmo padrão por pertencer à mesma rede municipal. As especificidades de cada unidade foram salientadas sem nenhuma pretensão de comparação. Foram levadas em consideração características específicas de cada unidade, mas sempre focalizando o objetivo principal que era caracterizar o AEE nestas escolas do campo. Participaram da pesquisa 31 professores de ensino regular que trabalhavam em uma ou mais escolas do campo do municipio escolhido para a pesquisa e atuavam em um ou vários dos três ciclos do Ensino Fundamental. Do contexto familiar, participaram 17 responsáveis pelos alunos que eram atendidos pelo serviço de AEE e a pesquisadora também foi participante, tendo em vista que era a Professora de Educação Especial atuante na Sala de Recursos Multifuncional das escolas selecionadas. 


\section{Resultados}

Apresentaremos dados sobre a caracterização das unidades, descrevendo a estrutura fisica das Salas de Recursos Multifuncional. Vamos apresentar um croqui do prédio de cada escola para mostrar a localização da Sala de Recurso Multifuncional em cada uma delas. Iniciaremos pela Escola A, na qual o prédio da creche funciona na mesma área da escola.

Figura 1: Croqui da Escola A

\section{Escola A}

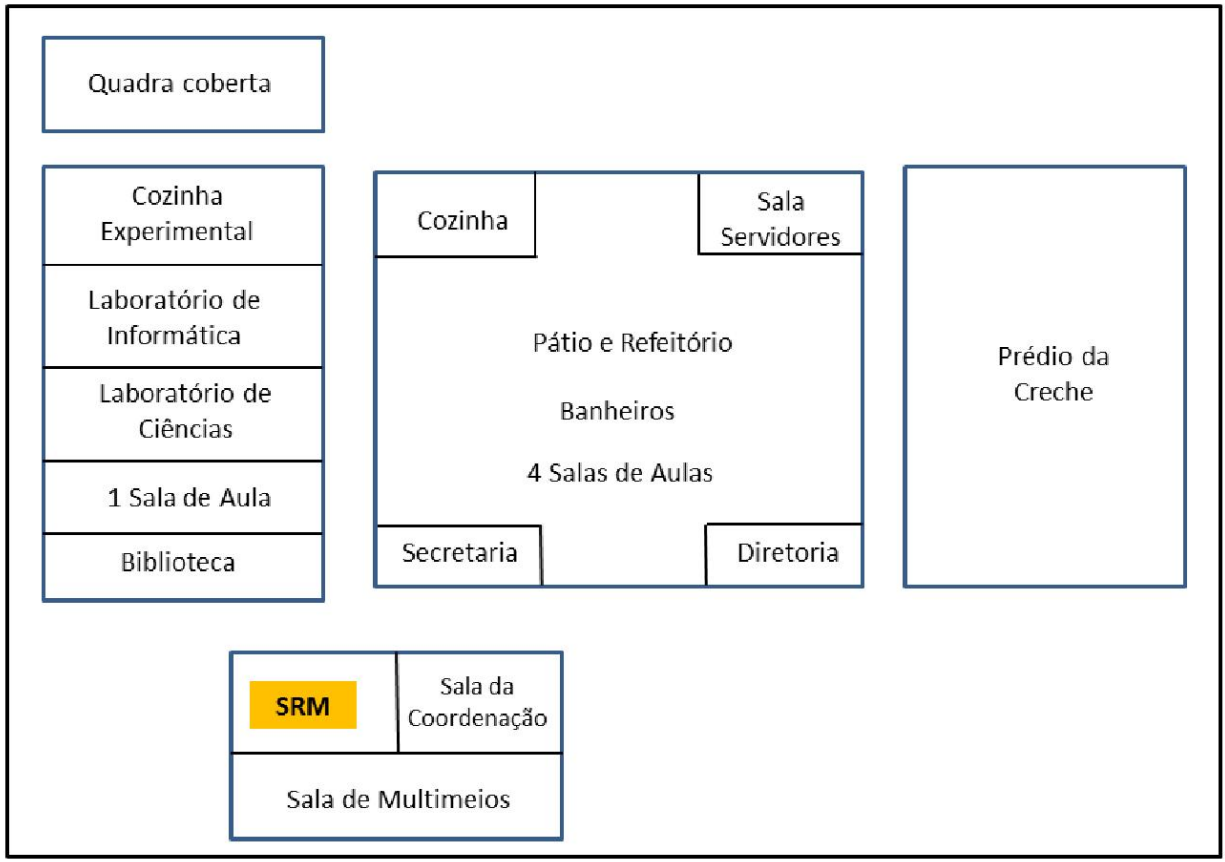

Fonte: Elaboração própria

A SRM da Escola A está localizada num anexo separado das salas de aula, no qual funciona a sala da Coordenação Pedagógica, a Sala de Multimeios e a SRM, este anexo foi construído por meio do Projeto "Da 
Palavra à Vida" do Programa Ação na Escola/2010 Parceria do Instituto Embraer de Educação e Pesquisa.

A SRM possui uma área de 3x3 metros e está equipada com duas mesas para computadores, uma mesa de impressora, uma mesa redonda com quatro cadeiras, um armário de aço para guardar os materiais e jogos, ventilador de parede, dois computadores, uma impressora e um notebook. Há duas portas de acesso para a sala, uma porta lateral que fica na divisória da Sala da Coordenação e uma porta de entrada, que não é ampliada para passagem de usuários de cadeiras de rodas.

Foi observado um problema em relação à acústica: as divisórias de policloreto de vinil, conhecido como PVC, não conseguem isolar o som das outras salas, o que causa um incômodo no desenvolvimento de atividades que exigem concentração e atenção, principalmente quando, na sala de Multimeios, o professor responsável utiliza filmes. As fotos abaixo ilustram este espaço:

Fotografia 1: Anexo onde está localizada a SRM



Fonte: Elaboração própria 
Fotografia 2: Porta de acesso à SRM

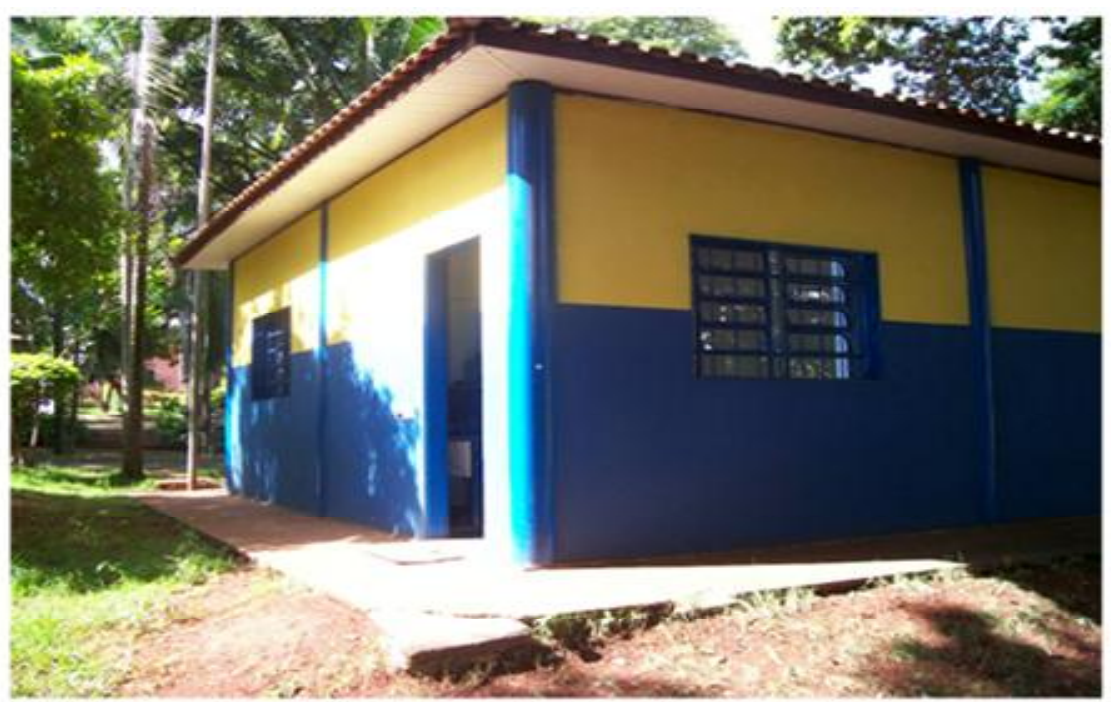

Fonte: Elaboração própria

Fotografia 3: Mesa redonda para as atividades

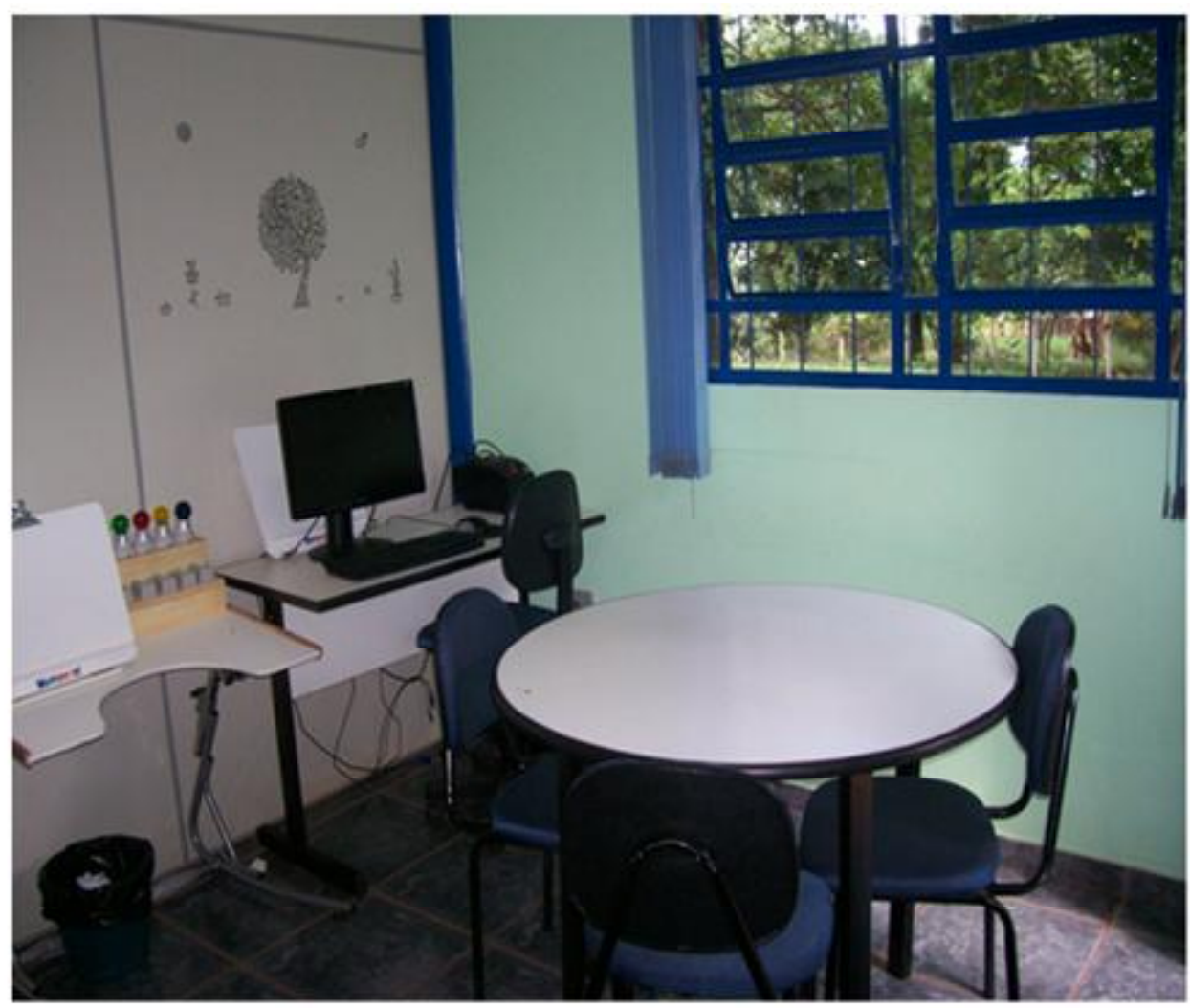

Fonte: Elaboração própria 
Fotografia 4: Armário



Fonte: Elaboração própria

Fotografia 5: Computador com impressora

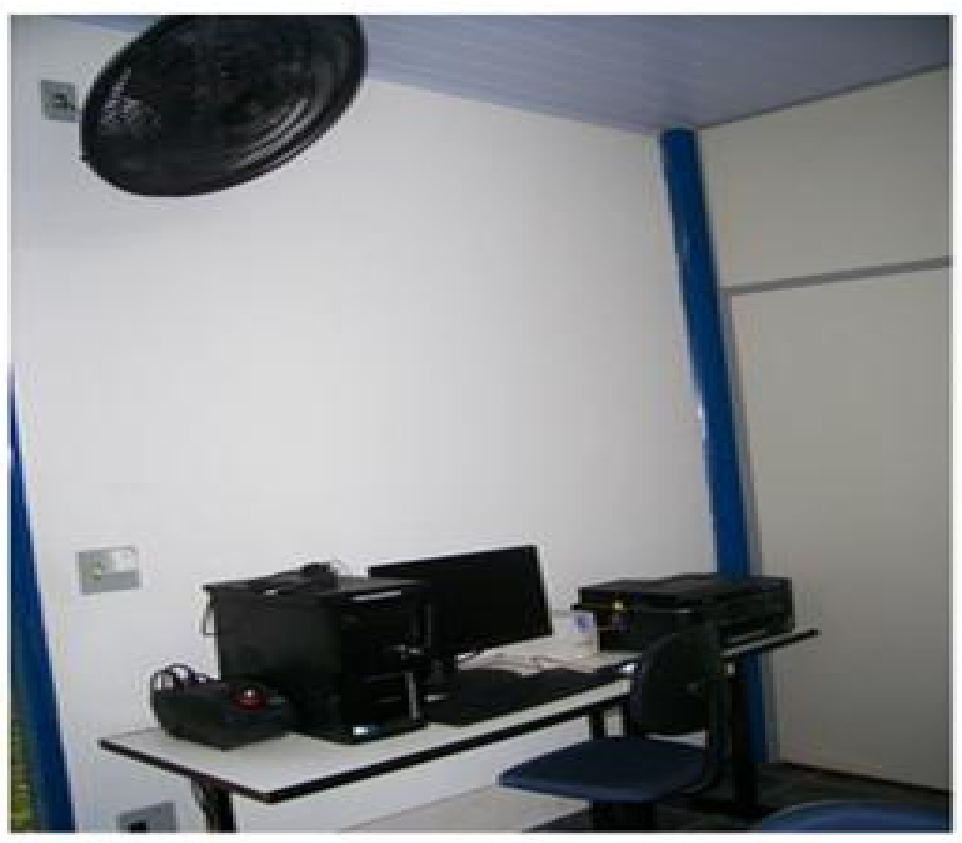

Fonte: Elaboração própria

A Escola B encontra-se estruturada da seguinte maneira: 
Figura 2: Croqui da Escola B

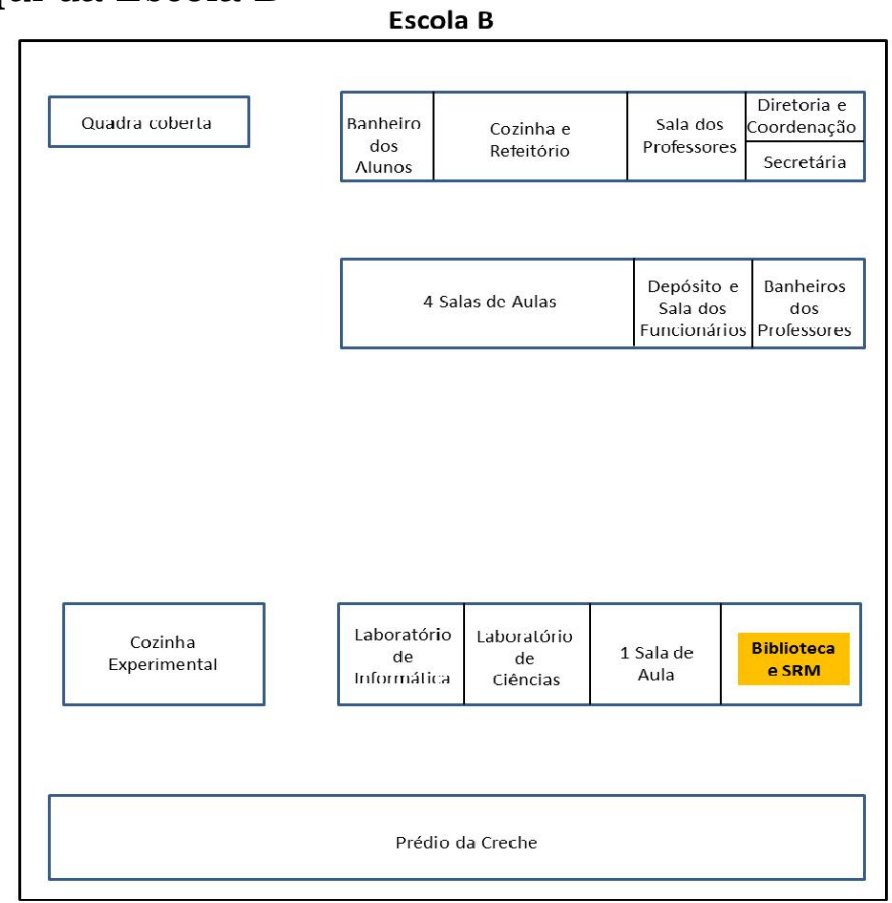

Fonte: Elaboração própria

A Escola B não possui SRM, a Professora do AEE compartilha o espaço da biblioteca para realizar o seu trabalho. Esta biblioteca fica em um anexo, junto com uma sala de aula do primeiro ano, o laboratório de ciências, o de informática e a cozinha experimental. E este complexo de salas fica entre o Centro de Educação Recreativa - CER e a Escola Municipal de Educação Fundamental - EMEF, conforme as fotos abaixo:

Fotografia 6: Corredor onde fica a biblioteca

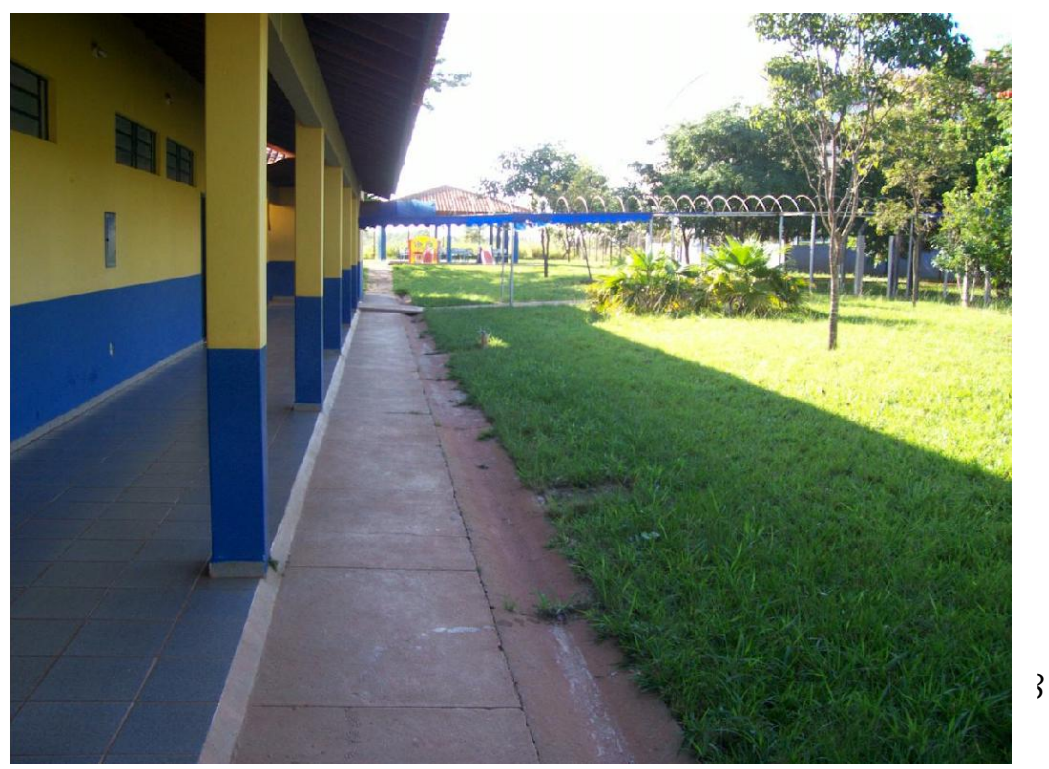


Fonte: Elaboração própria

Fotografia 7: Prédio da EMEF na parte de cima



Fonte: Elaboração própria

A biblioteca é ampla, possui várias estantes de livros, um espaço para leitura destinado às crianças pequenas, um aparelho de televisão com DVD para os professores utilizarem com vídeos, além da mesa e do armário da agente educacional responsável pela organização e manutenção deste espaço. A mesa e os armários da Educação Especial ficam localizados no fundo da sala, como podemos ver nas fotos abaixo:

Fotografia 8: Espaço da biblioteca destinado ao AEE

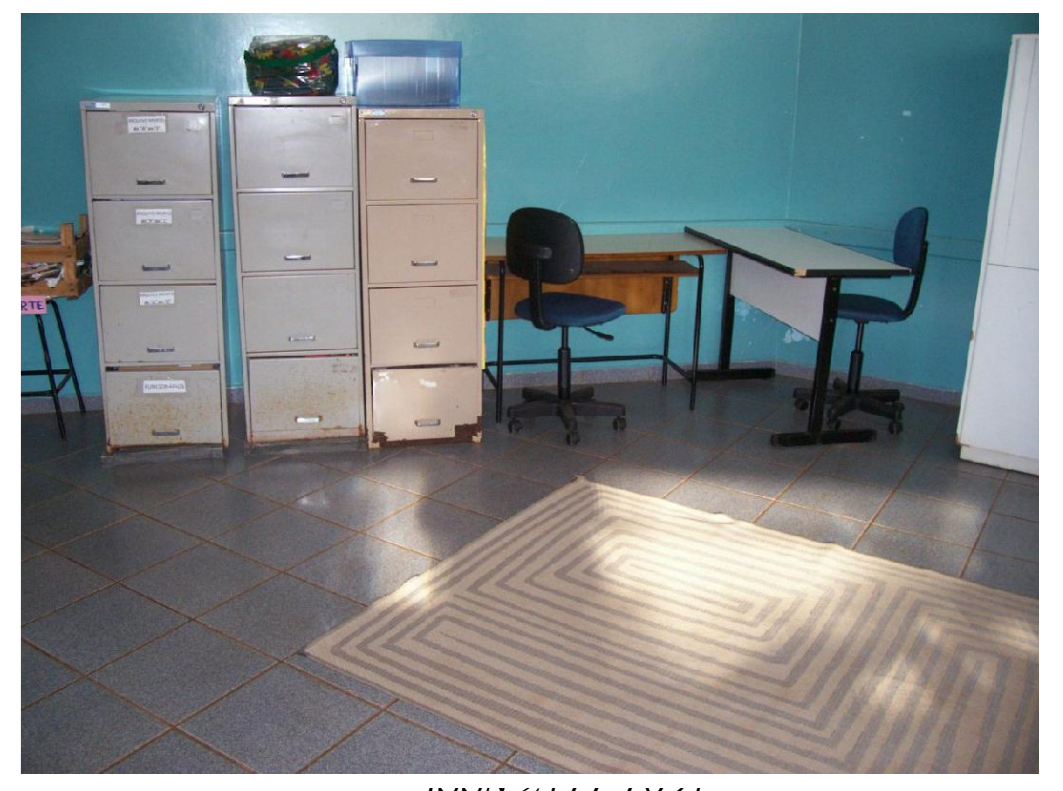


Fonte: Elaboração própria

Fotografia 9: Visão ampla da biblioteca

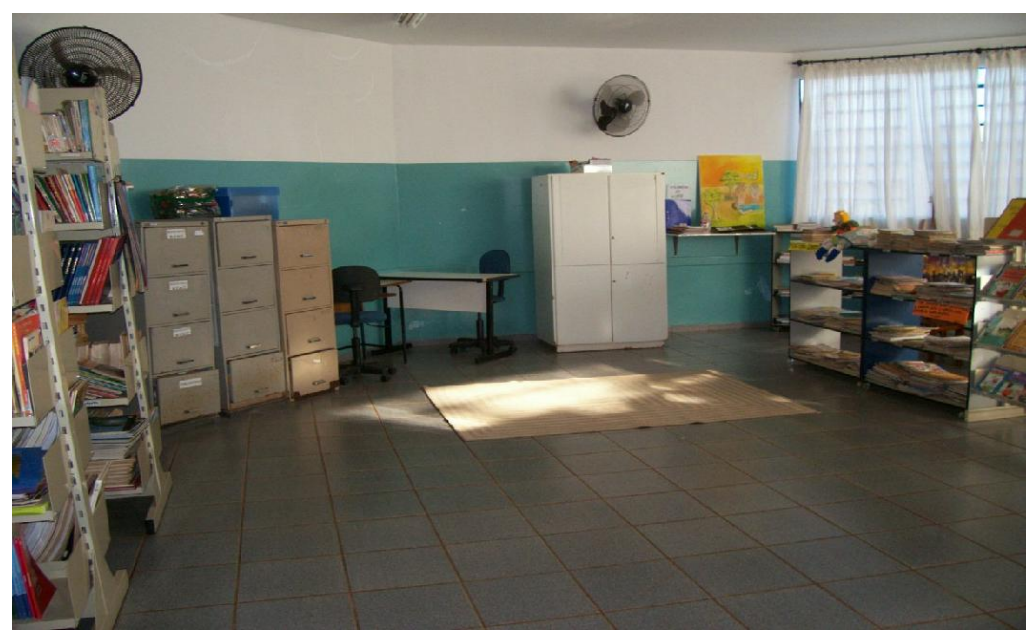

Fonte: Elaboração própria

Fotografia 10: Espaço para leitura da biblioteca

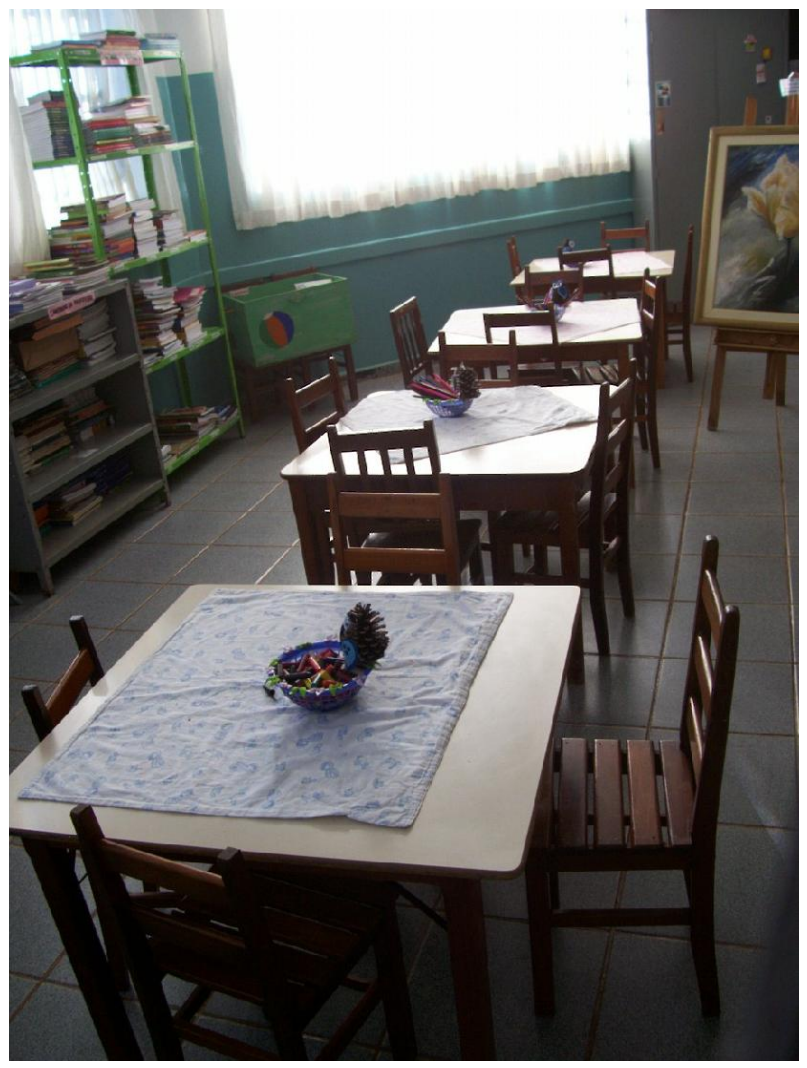

Interfaces da Educ., Paranaíba, v.9, n.27, p. 518-548, 2018 ISSN 2177-7691 
Fonte: Elaboração própria

$\mathrm{Na}$ Foto 8, visualizamos três arquivos, um pertence à Secretaria da escola e é utilizado como arquivo morto de documentos. Os outros dois são da Educação Especial, neles a professora guarda a documentação dos alunos e o material pedagógico específico para alunos com deficiência visual e auditiva que foram adquiridos por meio da verba de acessibilidade.

No dia da semana em que a Professora da Educação Especial realiza o AEE, a biblioteca não pode ser utilizada por nenhum professor da escola. Mesmo assim, observaram-se interrupções de alunos que solicitam dicionários, de professores que precisaram buscar algum livro específico e até mesmo de outros funcionários que procuraram a agente educacional para dar algum recado ou solicitar apoio em outras atividades da escola.

Por último, vamos falar da estrutura da Escola C, que se organiza da seguinte maneira:

Figura 3: Croqui da Escola C

Escola C

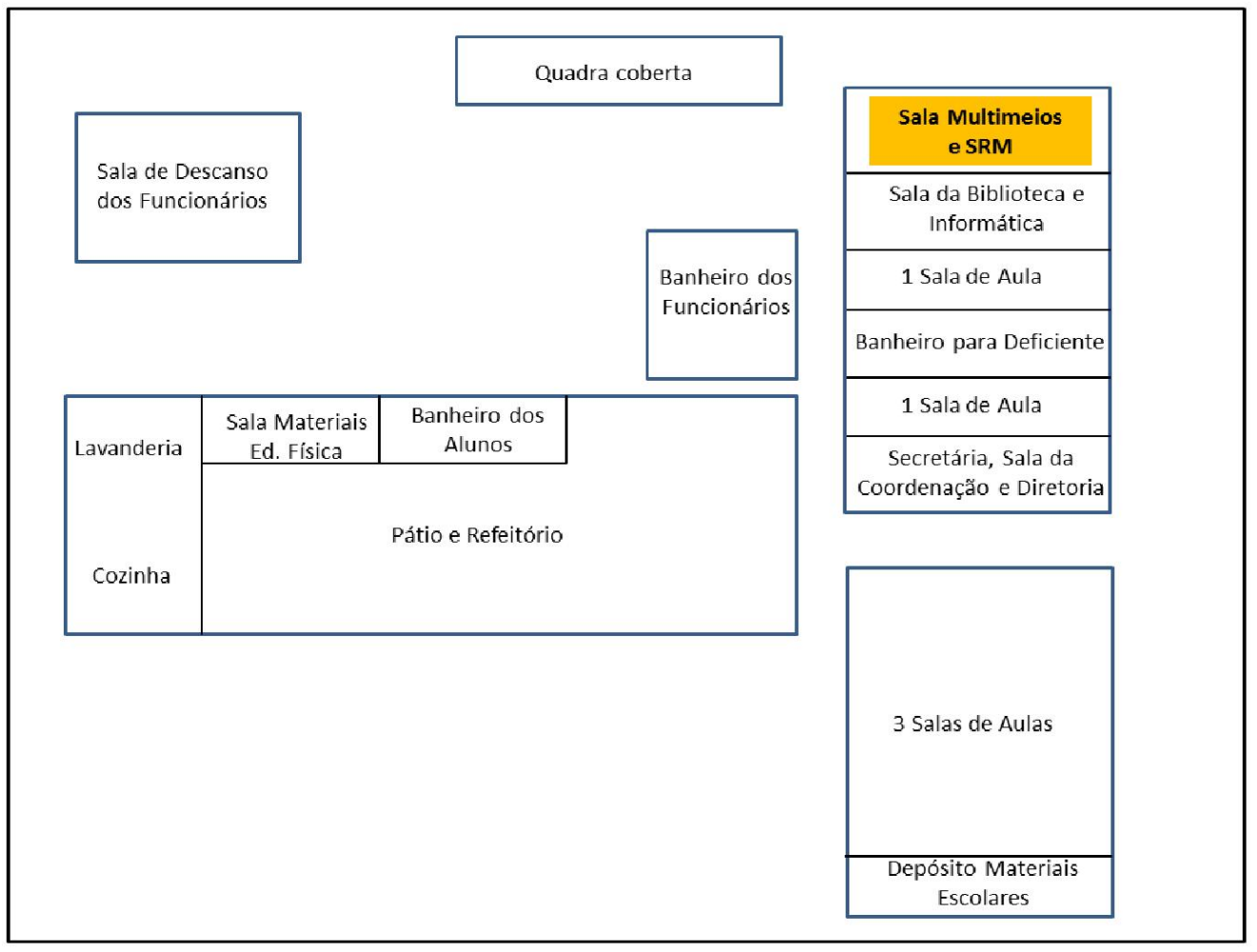


Fonte: Elaboração própria

A Escola C também não possui SRM. O trabalho do AEE é realizado numa sala que tem múltiplas funções. Essa sala é utilizada como sala dos professores, sala de aula para o período integral e sala de Multimeios por possuir a lousa digital que é utilizada pelos professores para passar vídeos aos alunos.

A sala possui um espaço amplo, mas que se tornou pequeno tendo em vista a lousa digital, as carteiras para os alunos, a mesa para o professor e, no fundo da sala, as mesas, computadores e armário da Educação Especial. Podemos visualizar melhor com as fotos:

Fotografia 11: Espaço de sala de aula

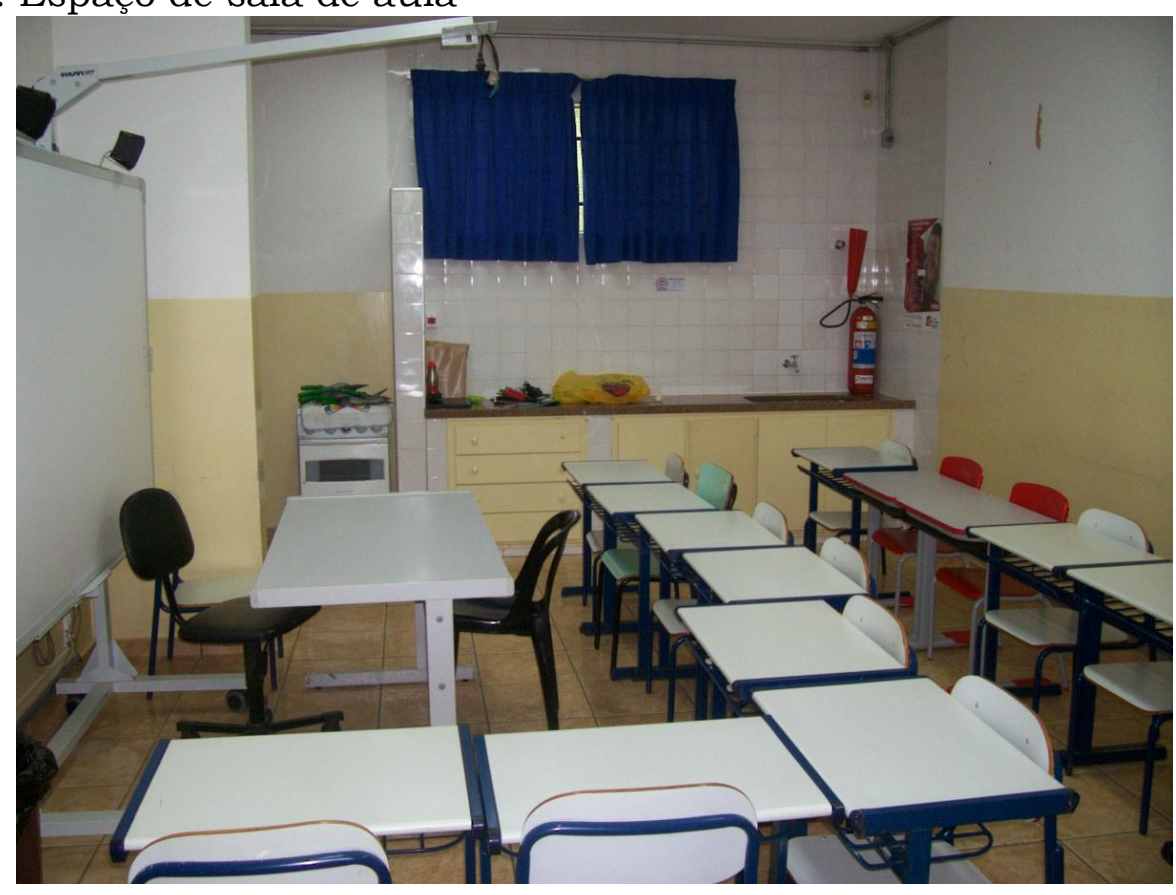

Fonte: Elaboração própria 
Fotografia 12: Espaço do AEE

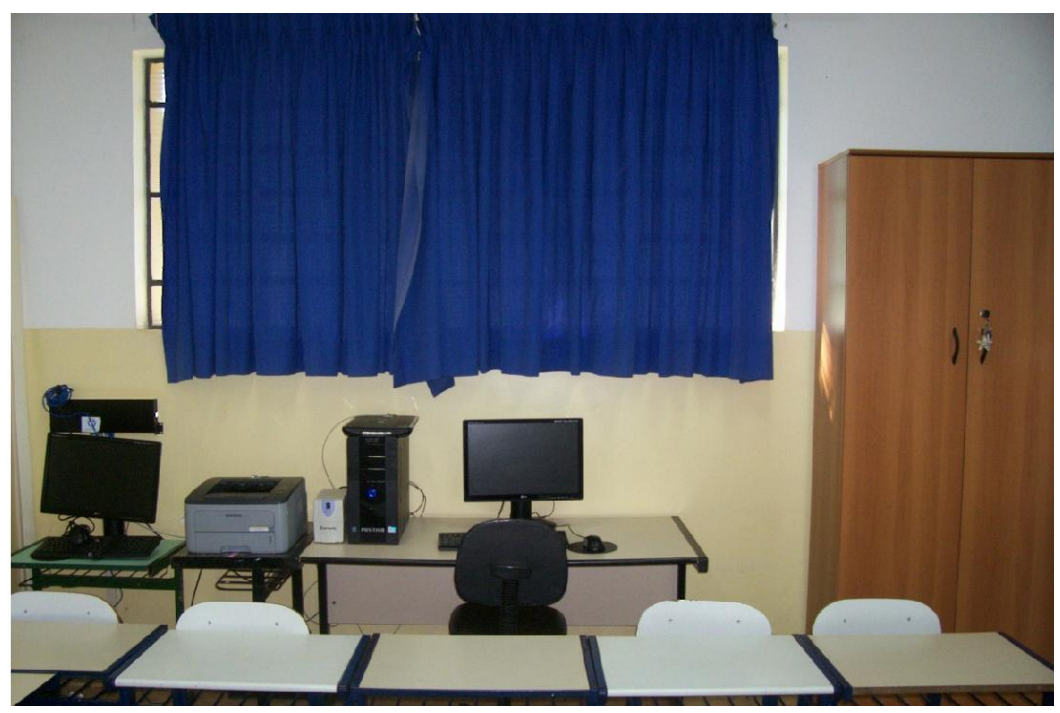

Fonte: Elaboração própria

Fotografia 13: Lousa Digital



Interfaces da Educ., Paranaíba, v.9, n.27, p. 518-548, 2018

ISSN 2177-7691 
Fonte: Elaboração própria

Fotografia 14: Armário do período integral

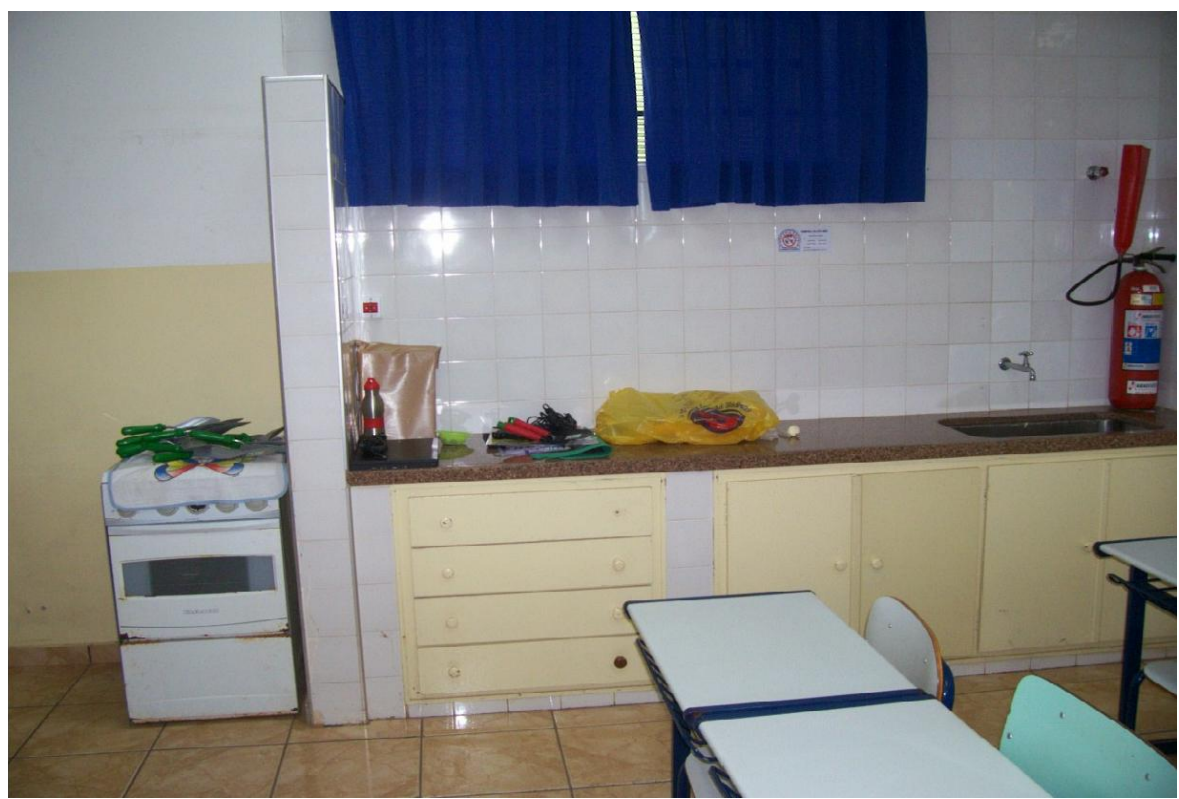

Fonte: Elaboração própria

É possivel perceber pelas Fotos 11 e 12 que é muito difícil chegar até o final da sala e que quase não tem espaço para movimentação devido ao posicionamento das carteiras. Quando a professora do AEE não realiza atividade no computador, ela usa a mesa do professor que consta na Foto 13. Também foi observado problema de interrupção do trabalho sempre no período da tarde, quando os alunos da Educação Integral precisam pegar material para as oficinas, os quais ficam guardados no armário embaixo da pia, conforme a Foto 14. Durante o dia de atendimento da Educação Especial esta sala não pode ser utilizada por outros setores da escola, mas mesmo assim, pela escassez de estrutura na escola, ocorrem interrupções.

Percebemos que nas Escolas B e C a sala destinada à Educação Especial é inadequada, fato indicador de que esta modalidade de educação ainda não tem prioridade dentro da unidade escolar. No caso da Escola B, 
que possui uma estrutura mais ampla, poderia se planejar para dividir a biblioteca com divisórias de PVC para que a Educação Especial tivesse um espaço organizado e reservado para realizar o trabalho com os alunos. Em se tratando da Escola C, o caso é mais complicado porque o prédio é muito antigo e foi construído para funcionar como creche e, depois de algum tempo, se transformou em escola. A estrutura física não contempla todas as demandas da unidade, a própria diretoria funciona numa sala pequena juntamente com a Coordenação Pedagógica e a Secretaria. Há alguns anos, a escola está aguardando uma ampliação para atender melhor os alunos, resolvendo os problemas de estrutura física.

\section{Discussão}

Em relação ao funcionamento da SRM nestas unidades do campo, ele ocorre no mesmo período de aula. Apesar da legislação regulamentar, o contra turno é totalmente inviável para os alunos, porque não existe transporte agendado para horários diferentes da rotina de entrada e saída escolar.

O assentamento é dividido em lotes e a maioria deles fica distante da escola, sendo assim, as crianças dependem do transporte para chegar à escola e retornar as suas casas. No caso de a criança ficar no período oposto para frequentar o AEE, ela não terá como ir embora, ficará esperando por mais de quatro horas pelo transporte.

Assim sendo, o aluno é retirado da sala de aula regular uma vez por semana para ter o AEE, que tem duração de 50 minutos, ou seja, o tempo de uma aula.

No momento de elaboração da política pública de operacionalização do AEE na Educação Básica foi definido que o turno inverso seria o mais adequado, conforme consta na Resolução No $4 \mathrm{CNE} / \mathrm{CEB}$, artigo $5^{\circ}$ :

O AEE é realizado, prioritariamente, na sala de recursos multifuncionais da própria escola ou em outra escola de ensino regular, no turno inverso da escolarização, não sendo substitutivo às classes comuns, podendo ser realizado, também, em centro de Atendimento Educacional Especializado da rede pública ou de instituições comunitárias, confessionais ou filantrópicas sem fins 
lucrativos, conveniadas com a Secretaria de Educação ou órgão equivalente dos Estados, Distrito Federal ou dos Municípios. (BRASIL, 2009)

No entanto, não foi levada em consideração a particularidade das escolas do campo. É necessário que se criem politicas públicas que garantam transporte para que os alunos do campo frequentem o $\mathrm{AEE}$ no turno inverso, com horários adequados e sem longas esperas para o retorno às suas casas.

O Gráfico 1 apresenta o grau de satisfação em relação ao espaço físico:

Gráfico 1 - Avaliação da Estrutura Física da SRM

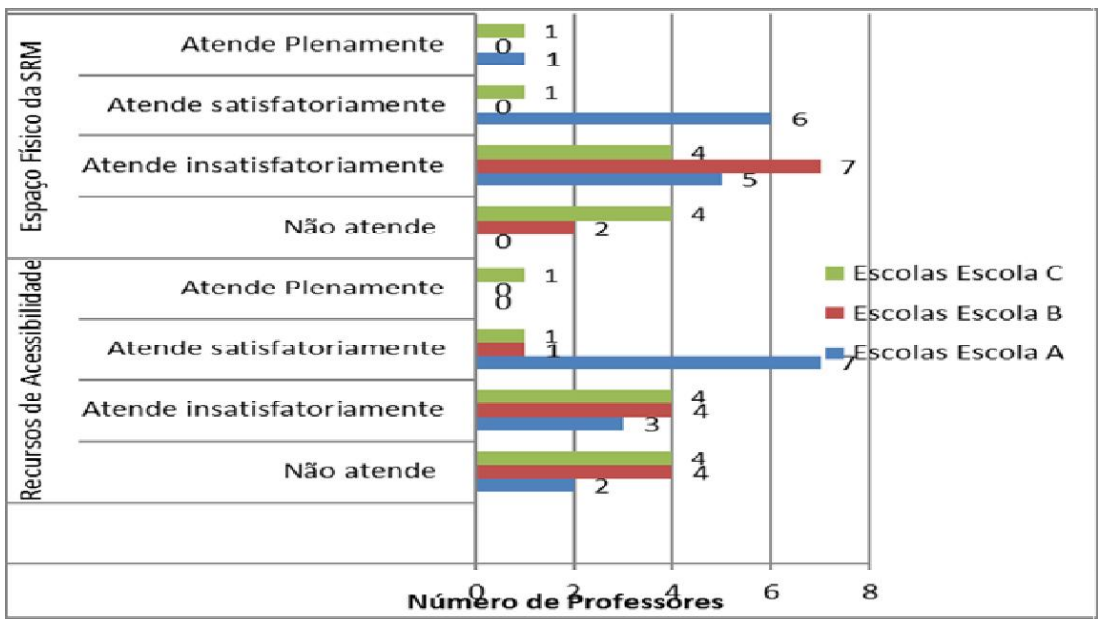

Fonte: Elaboração própria

Quanto ao espaço físico da SRM da Escola A, seis professores apontam que atende satisfatoriamente e um deles apontou plenamente. A parcela de cinco professores que considera insatisfatório inseriu os seguintes comentários no questionário:

"Fator barulho, pois tem uma divisória que separa a sala de aula e a coordenação."

"Sala pequena, paredes não isolam do som externo".

Em relação aos recursos de acessibilidade da Escola A, temos sete professores que consideram satisfatório. Os demais apontaram que não atende (dois) ou que está insatisfatório e (três) justificam: 
"Deveria ter mais oportunidade de acesso de alunos cadeirantes (não há rampa) assim como para os alunos com deficiência visual".

"Não possui rampa".

Analisando a Escola B, o espaço da SRM é insatisfatório para sete professores e os recursos de acessibilidade são insatisfatórios (quatro) ou não atende (quatro) à demanda. Tivemos os seguintes comentários:

"Não há sala de recursos."

"Não há este espaço, a professora atende em um pedacinho da biblioteca".

"Não há uma sala específica para o Atendimento e por isso o trabalho é feito na Biblioteca da escola".

"Infelizmente a escola não oferece um espaço próprio para atender os alunos da Educação Especial. Em relação aos recursos, a escola dispõe de jogos, alfabeto móvel e brinquedos que favorecem o aprendizado destes alunos”.

Por último, na Escola C, os professores também apontam que o espaço da SRM é insatisfatório (quatro) ou não atende (quatro) à demanda. Os números se repetem em relação aos recursos de acessibilidade.

\footnotetext{
"A escola não possui sala de recursos e não atende de forma plena, pois a professora não está em um espaço adequado".

"Na escola não há uma sala que atende as necessidades de acessibilidade".

"O espaço não é próprio e é dividido com outras funções".
}

\section{Realidade atual da sala de recursos}

Dois anos após a pesquisa, em visita informal às unidades escolares, identificou-se ainda uma realidade de direitos negados em relação à garantia do espaço para se efetivar o AEE.

$\mathrm{Na}$ Escola A, única que possuía um espaço adequado, a sala de recursos multifuncionais deixou de existir. A sala em questão foi transformada em sala de aula e atende a uma turma de terceiro ano. A Sala de Recursos Multifuncionais funciona na área em frente à Secretaria, com uma divisória. Os recursos tecnológicos e pedagógicos não ficam neste ambiente porque, apesar da divisória, é uma área aberta sem janela. O fluxo 
de pessoas também é intenso o que dificulta o trabalho realizado com os alunos.

A Escola B transferiu a sala de recursos da biblioteca para o Laboratório de Informática. No dia em que a professora especialista utiliza a sala, os alunos e professores não podem acessar o laboratório.

Por fim, a Escola C continua no mesmo espaço apontado na pesquisa, porém com mais rotatividade. Muitas vezes, para atender à demanda da escola, a professora especialista tem que atender e trabalhar com seus alunos na Sala da Assistente Educacional Especializada.

\section{Considerações finais}

Desde quando existiam as Classes Especiais, foi identificado por Dal Pogetto (1987) insatisfação em relação ao espaço físico destinado ao trabalho com as pessoas com deficiência.

A SRM tem a mesma importância de uma sala de aula regular, porém nas escolas do campo pesquisadas isto não ocorre. A raiz deste problema ficará em aberto para próximas pesquisas, mas cabe uma reflexão. Este fenômeno ocorre somente em escolas do campo? Será que ainda existe a visão do campo como lugar de atraso, por isso a falta de investimento na melhoria do espaço físico das escolas?

O espaço temporário e transitório para a Educação Especial nas escolas pode refletir o olhar temporário e transitório sobre o aluno com deficiência, no sentido de não considerá-lo como parte da escola, de deixá-lo ali com a matrícula efetivada, porém sem os recursos necessários para sua efetiva aprendizagem.

\section{Referências}

ARROYO, M. G. Por um tratamento público da Educação do Campo. In: MOLINA, M. C.; JESUS, S. M. S. A. (orgs.). Contribuições para a Construção de um Projeto Politico de Educação do Campo. Brasília, DF: Articulação Nacional "Por Uma Educação do Campo", 2004, p.91-108. (Por Uma Educação do Campo, 5). 
BRASIL. Constituição. Constituição da República Federativa do Brasil. Brasília, DF: Senado Federal: Centro Gráfico, 1988.

. Ministério da Educação. Politica Nacional de Educação Especial na Perspectiva da Educação Inclusiva. Brasília: MEC, 2008a. Disponível em: <http://www.mec.gov.br> Acesso em: 16 nov. 2012.

. Ministério da Educação. Decreto 7.611 de 17 de novembro de 2011. Dispõe sobre a Educação Especial, o atendimento educacional especializado e dá outras providências. 2011. Disponivel em:

<http://www.planalto.gov.br> Acesso em: 16 nov. 2012.

. Ministério da Educação. Conselho Nacional de Educação. Câmara de Educação Básica. Resolução $n^{\circ}$ 2, de 28 de abril de 2008c. Estabelece diretrizes complementares, normas e princípios para o desenvolvimento de políticas públicas de atendimento da Educação Básica do Campo, 2008c. Disponivel em: <http://www.mec.gov.br>. Acesso em: 16 nov. 2012.

.. Ministério da Educação. Secretaria de Educação Especial. Resolução 4/2009. Institui Diretrizes Operacionais para o Atendimento Educacional Especializado na Educação Básica, modalidade Educação Especial. 2009 Disponivel em:

<http:/ / portal.mec.gov.br/dmdocuments/rceb004_09.pdf> Acesso em: 20 ago. 2018

. Ministério da Educação. Decreto 7.352 de 04 de novembro de 2010. Dispõe sobre a política de educação do campo e o Programa Nacional de Educação na Reforma Agrária -PRONERA. 2010. Disponível em: <http://www.planalto.gov.br/ccivil_03/_ato20072010/2010/decreto/d7352.htm> Acesso em: 23 mar. 2016.

Lei $n^{\circ} 13.005$ de 25 de junho de 2014. Aprova o Plano Nacional de Educação - PNE. 2014. Disponivel em: <http:/ /www2.camara.leg.br/legin/fed/lei/2014/lei-13005-25-junho-2014778970-publicacaooriginal-144468-pl.html> Acesso em: 23 mar. 2016.

CAIADO, K. R. M.; MELETTI, S. M. F., Educação Especial na Educação do Campo: 20 anos de silêncio no GT15. Revista Brasileira de Educação Especial, Marília, v.17, Maio-Ago., p.93-104, 2011a.

CAIADO, K. R. M; MELETTI, S. M. F. Educação Especial na Educação do Campo no Estado de São Paulo: Uma interface a ser construída. In: BEZERRA NETO, L.; BEZERRA, M. C. S. (orgs.) Educação para o campo em Discussão: reflexões sobre o Programa Escola Ativa. São José: Premier, 2011b. p.171 -185

CALDART, R. S. Elementos para construção do Projeto político e Pedagógico da Educação do Campo. In: MOLINA, M. C; JESUS, S. M. S. A. (orgs.). 
Contribuições para a Construção de um Projeto Politico de Educação do Campo. Brasília, DF: Articulação Nacional "Por Uma Educação do Campo", 2004, p.13-52. (Por Uma Educação do Campo, 5).

CALDART, R. S. Sobre educação do Campo. In: SANTOS, C. A. et al. (org.) Educação do Campo: campo, políticas públicas e educação. Brasília, DF:

INCRA/MDA, 2008, p.67-86. (Coleção Por Uma Educação do Campo, v. 7).

DAL POGETTO, M. T. D. P., Como professores de Classe Especial para Deficientes Mentais da Rede Estadual de ensino percebem sua atuação profissional. Dissertação (Mestrado em Educação Especial). Universidade Federal de São Carlos, 1987.

PIOVESAN, F. Concepção Contemporânea de Direitos Humanos. In HADDAD, S. A.; GRACIANO, M. (orgs.). A Educação entre os Direitos Humanos. Campinas, SP: Autores Associados; São Paulo, SP: Ação Educativa, 2006. p.11-42. 